\title{
God-image of Servant King as powerful but vulnerable and serving: Towards transforming African church leadership at an intersection of African kingship and biblical kingship to servant leadership
}

\begin{tabular}{|c|c|}
\hline \multicolumn{2}{|c|}{$\begin{array}{l}\text { Author: } \\
\text { Vhumani Magezi }{ }^{1}\end{array}$} \\
\hline \multicolumn{2}{|c|}{$\begin{array}{l}\text { Affiliation: } \\
{ }^{1} \text { Faculty of Humanities, } \\
\text { School of Basic Sciences, } \\
\text { North-West University, Vaal } \\
\text { Triangle Campus, } \\
\text { South Africa }\end{array}$} \\
\hline \multicolumn{2}{|c|}{$\begin{array}{l}\text { This article is a reworking of } \\
\text { a paper that was presented } \\
\text { at Practical Theology } \\
\text { Conference of South Africa in } \\
2015 \text {. This article is published } \\
\text { in the section Practical } \\
\text { Theology of the Society for } \\
\text { Practical Theology in } \\
\text { South Africa. }\end{array}$} \\
\hline \multicolumn{2}{|c|}{$\begin{array}{l}\text { Correspondence to: } \\
\text { Vhumani Magezi }\end{array}$} \\
\hline \multicolumn{2}{|c|}{$\begin{array}{l}\text { Email: } \\
\text { vhumani@hotmail.com }\end{array}$} \\
\hline \multicolumn{2}{|c|}{$\begin{array}{l}\text { Postal address: } \\
\text { North-West University, Vaal } \\
\text { Triangle Campus, Faculty of } \\
\text { Humanities, School of Basic } \\
\text { Sciences, Hendrik van Eck } \\
\text { Blvd, Vanderbijlpark 1900, } \\
\text { South Africa }\end{array}$} \\
\hline $\begin{array}{l}\text { Dates: } \\
\text { Received: } 11 \\
\text { Accepted: } 12 \\
\text { Published: } 16\end{array}$ & $\begin{array}{l}\text { eb. } 2015 \\
\text { uuly } 2015 \\
\text { Nov. } 2015\end{array}$ \\
\hline \multicolumn{2}{|c|}{$\begin{array}{l}\text { How to cite this article: } \\
\text { Magezi, V., 2015, 'God-image } \\
\text { of Servant King as powerful } \\
\text { but vulnerable and serving: } \\
\text { Towards transforming } \\
\text { African church leadership } \\
\text { at an intersection of African } \\
\text { kingship and biblical kingship } \\
\text { to servant leadership', } \\
\text { HTS Teologiese Studies/ } \\
\text { Theological Studies 71(2), } \\
\text { Art. \#2907, } 9 \text { pages. http:// } \\
\text { dx.doi.org/10.4102/hts. } \\
\text { v71i2.2907 }\end{array}$} \\
\hline Read online: & \\
\hline 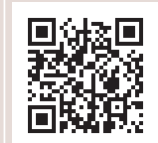 & $\begin{array}{l}\text { Scan this QR } \\
\text { code with your } \\
\text { smart phone or } \\
\text { mobile device } \\
\text { to read online. }\end{array}$ \\
\hline
\end{tabular}

Christianity is mediated through culture and people's cultural practices. One such cultural practice is African kingship. African kingship conveys on the ruler sovereignty, power, authority and supremacy over people under one's jurisdiction. Intricately linked to respect for elders and those in power, African church leaders are at an intersection of the African kingship leadership style and the biblical kingship leadership style. Consciously or unconsciously, church leaders tend to embrace the African kingship approach to leadership and to a lesser extent biblical servant leadership. In such a situation, what God-image of biblical leadership could be discerned for constructive church leadership? In response, the God-image of Servant King as all powerful God, although vulnerable and serving, provides the framework for a transformative approach to church leadership in Africa.

\section{Introduction and background}

Leadership is a nebulous concept, yet fascinating. Implicitly, every institution and social unit attests to the pivotal role of leadership. At home, parents refer to some children as leaders of other children either for good or bad; youth groups claim to engage in initiatives to develop leaders; churches focus a great deal on efforts to develop their leaders, while organisations expend significant resources on leadership development. Van Dyk and Van Niekerk (2004:1) observe that leadership is a popular topic because of the assumed role it plays in group and organisational effectiveness. The success of a group or organisation depends primarily on the quality of its leadership. The pivotal role of leadership in society and organisations cannot be emphasised enough (Mostert 2005:1; Nkomo 2006:1; Swart 2008:10; Van Dyk \& Van Niekerk 2004:1).

Within the context of globalisation where boundaries have melted away (Ceglowski 1998:1) and multinational corporations are exerting energies and resources in creating corporate cultures across countries to ensure brand and product uniformity, the situation begs the question regarding the role and influence of cultural context on leadership. Guenther and Heidebrecht (1999:5) explain that historically leadership has always been influenced by specific cultural and philosophical frameworks. Thus, they advance a contextual approach to leadership. They advise that the process of identifying, designing and practising leadership should be informed by the context in which leadership is practised. O'Malley (2003:2-3) adds that situational variables of leadership are a modern feature of assessing leadership effectiveness. Following this contextual thread of leadership, Mostert (2005:2) and Smit (2012:1) state that African leadership therefore should import some of the African concepts, philosophy and approaches for effectiveness. The term Africa used in this article refers to sub-Saharan Africa. Within the broader concept of African leadership, the focus of this article is on the aspects of people's practices of kingship and gerontocracy.

The key features that influence African leadership are kingship, gerontocracy and other cultural values such as interdependence, communalism, relationship-awareness and respectfulness. This cultural influence on leadership has, however, both positive and negative effects. Focusing on kingship, Oladosu (2005:2) argues that African kingship and monarchies in many instances were founded on war and conquest. African kingship institutions are said to be derived from intellectual pretence whereby kingship is so noble that the monarchs are to be credited with the divine right to reign as the legally-illimitable, supreme sovereigns over their subjects. This therefore leads to kings who are autocratic, unchallenged and oppressive towards their subjects, including even 
their own families. O'Malley (2003:48), citing Mufuka and other African scholars, chronicles numerous incidents of brutality among kings in their kingdoms across Southern, West and East Africa. Hence, although discouraged, it is understandable why significant numbers of African church leaders emerging from the African continent adopt the kingship model of leadership and its associated nuances. As Guenther and Heidebrecht (1999:1) add, leadership models used by the church over the years have been adopted, in part, because of their practical function within a specific cultural and philosophical framework. Leadership models continue to reflect the adaptation of the church to new circumstances and cultures.

Importantly, kingship in our discussion is generically used to denote traditional African leadership where kingship and gerontocracy related traditional practices influence and shape leadership style. These leaders could be males or females. For instance, Pfarelo (2013:1) in his doctoral thesis clearly describes how female leaders influence traditional leadership. He argues that even though in many communities women are subordinate to men, there are special classes of women who play critical roles in the public sphere and whom the society regards highly. These women shape the mode and style of leadership in community or home. In the case of the Venda people these are the makhadzi, the sisters of one's father. Pfarelo (2013:1) states that even though these women are not explicitly recognised by legislation, they yield power and influence. There is a long list of African women leaders who function like kings and shape leadership styles in Africa, just like their male counterparts. ${ }^{1}$

The traditional African approach to leadership, largely influenced by kingship and gerontocracy, tends to influence general African leadership styles. Alexander (2012:2) insightfully reveals an important African leadership dynamic. She asks, 'Why do so many African leaders die in office?' She observes that it is rare for the leader of a country to die in office, but from 2008 to 2012 it happened thirteen times worldwide and ten of those leaders were in Africa. The question is, why in Africa? She states: 'The obvious answer is that African leaders are just older than those of other continents.' She adds: '[I]t is believed Africans like their leaders to be older' (my emphasis). Respect for elders is embedded in the culture of many African countries (Magezi 2006:2). She illustrates her point by comparing the average age of serving African leaders to those of the other continents. The average ages indicate that the average age of African leaders is higher than those of other continents.

Ascribed kingship and gerontocracy leadership is often not questioned. The people in leadership often wield too much power and are feared. Igué (2009:18) notes that many African societies function on the basis of fear and that they find it difficult to introduce initiatives that may bring progress. A similar trend is evident in churches. The leadership comprises people who are elderly, whom the majority reveres and to whom unquestionable status and authority is conferred. Arguably, while this church leadership approach draws from the traditional African practice of kingship and gerontocracy, it is at variance with the biblical model of servant leadership. Therefore, African church leaders are challenged to develop a constructive African church leadership approach that appropriately integrates African traditional kingship and biblical servant leadership approaches. In view of this, how could some African church leaders whose culture and background are derived to a considerable extent from the African kingship model shift to a biblical kingship model to employ biblical servant leadership? What are some of the African leadership elements that could be adopted for sound biblical servant leadership? Could a theological conception of God be identified which utilises the God language of kingship and that could be employed for constructive and sound church leadership?

The following proposition is made to respond to the above questions: A paradoxical God image of Servant King, as king with power, but vulnerable and serving, is proposed as a practical theological approach to transform African church leadership at an intersection of the influence of African kingship culture and an understanding of biblical kingship to servant leadership. To consider the above subject, the discussion will first outline the definition of leadership as well as review African leadership and its associated characteristics. Secondly, servant leadership will be discussed with a focus on differentiating biblical servant leadership from general servant leadership in management and leadership literature. Thirdly, an integrated transformational leadership model employing a paradoxical God-image of Servant King, as king with power but vulnerable and serving, will be proposed as a constructive church leadership model.

\section{Definition of leadership - An operational definition}

Notwithstanding the undisputed role of leadership in daily living, the concept is understood differently depending on the context, be it at home, in church or, for instance, within Wall Street corporations. At home, the focus on children could be to ensure that older siblings lead younger ones in conforming to household and family ideals. At church, the concern could be to ensure that those who hold positions of authority discharge their duties in support of the pastor to effectively advance the goal of the church. Finally, for Wall Street corporations, leadership may entail ensuring that investors realise optimum returns on their investments. Due to these myriad views on the concept, it may arguably be futile to attempt a meaningful discussion on the subject of leadership. Nonetheless, it would be irresponsible to proceed without framing a guiding definitional framework on the concept of leadership.

Rost (1993:37) and Barker (2002:5-10), both cited by Winston and Patterson (2006:6-7), reviewed definitions of leadership in order to formulate a concise definition, but the conclusions 
were unconvincing. Winston and Patterson (2006:7) note that Rost concluded his work with a reductionistic five-point definition of leadership while Barker, in a similar manner, reductionistically concluded that leadership is about two things: process and behaviour. In order to avoid the pitfalls of their research predecessors, Winston and Patterson (2006:8) have opted for an integrative definition of leadership that helps researchers and practitioners to more fully understand the breadth and scope of leadership as a concept. Winston and Patterson (2006:6) argue that leadership literature shows that parsimony may be a problem in understanding leadership. In contrast to parsimony, they uncovered over 90 variables of leadership constructs. These 90 variables constitute the integrative definition. These variables were derived from 160 reviewed articles and books on the definition of leadership. Thus, in their effort to provide a functional operational definition and to avoid a reductionistic definition, they have articulated an integrative definition, which turns out to be more than one page long. Unfortunately, such a definition is both cumbersome and confusing to apply.

In view of the above two extremes in articulating an operational definition of leadership, I suggest that the definition should be guided by the context of this article, namely, biblical servant leadership practised within the context of a faith community as a launch pad. Guenther and Heidebrecht (1999:1-2), as indicated above, uphold this contextualised approach to leadership. They maintain that the process of identifying, designing and practising leadership should be informed by the context in which leadership is practised. Also as indicated above, O'Malley (2003:3) adds that situational variables of leadership are a modern feature of assessing leadership. The operational framework of leadership that is proposed for the discussion in this article is expressed as follows: It is church leadership practised within the context of African leadership whereby the leadership is executed at the intersection of the realms of African kingship and biblical kingship leadership styles to inform Christian servant leadership. Albeit not a concise definition, this framework provides a compass for the discussion.

Therefore, guided by the above definition we proceed to provide an overview of the debate on African leadership with a view to delineating its features leading to a proposal for a functional model.

\section{African leadership conception - Variegated approaches}

The quest for a true and authentic African leadership definition has been a subject of discussion that sometimes evokes emotions among African scholars. The clear challenge that stands out is to articulate the meaning of African leadership. Nkomo (2006:1), in her insightful article 'In search of African leadership', wisely asks a provoking rhetoric question 'What does it mean to practise African leadership?' Nkomo (2006:1) proceeds to add that the question of African leadership does not have an easy answer, but requires a great deal of research, and the research should not shy away from the difficult questions that confront African leadership. In addressing the subject of African leadership, African scholars seem polarised. There are those who argue that the leadership approach should be abolished as it is derived from an oppressive kingship model, in line with the views of Oladosu (2005:2) and O'Malley (2003:2) mentioned above.

However, Onike (2012:1) in his essay, 'Kingship and gerontocracy as core African traditions', paints a positive image of African kingship. He observes that out of all African traditions, kingship and gerontocracy are two important cultural values that are cherished by the people of Africa. Although kingship conveys on the ruler the sovereignty, power, authority and supremacy over others, the king's authority is derived from the people. Even though the king has supreme authority, the system encourages checks and balances and separation of power between the traditional rulers and the kingmakers. O'Malley (2003:3) describes the utility of kingship by referring to the birth, growth and demise of Afrikaner leadership. He observes that the Khoisan's lack of elaborate leadership or kingship institutions contributed, in large measure, to their ruthless exploitation, while the Bantu groups were saved from similar harsh treatment by the protection offered them by relatively strong traditional kingship leadership systems even though these were eventually conquered by a combination of British and Boer military might.

In view of the above, it is observed that the role of African kingship albeit controversial is the bedrock of African leadership. Mostert (2005:2) advises that African leadership has to import relevant ideas stemming from African thought and philosophy for effective leadership. Similarly, Nkomo (2006:1-2) notes that the efforts of African philosophers to articulate African leadership tenets is an attempt to correct the lack of acknowledgement or omission of the existence of leadership in pre-colonial Africa that should inform contemporary leadership approaches. Notably, African leaders are influenced by their tradition and culture, explicitly or implicitly. Smit (2012:2) in his essay, 'Leadership challenge for Africa', observes two perspectives that stood out in his interviews with black African leaders. The first perspective is the impact of culture and tradition in the sense that some leaders preferred informality and showed aversion to structure and reluctance to take a stand, set the agenda and lead for a righteous cause. The second perspective is the polarity that African leaders often experience whereby on the one hand there is the Western emphasis on practical, merit based, bottom-line effectiveness and, on the other hand, the Africans' preference to be interdependent, communal, relationship-aware and respectful. Smit (2012:2) therefore concludes that in order to be successful, leaders of Africa have to earn followers from both perspectives and they have to lead confidently within this paradox.

The above discussion reveals that the debate on African leadership is inconclusive and the views are variegated. However, the guiding questions that should be posed to resolve the above inconclusive views on African leadership 
are: what are the overarching features or characteristics of African leadership that should be noted? What are the leadership tenets that can be discerned from African traditional leadership that could be employed for an integrated church servant leadership model?

\section{A treasure hunt: Towards lifting the veil on African leadership}

For lack of a better subtitle, I have likened the efforts to articulate aspects of African leadership to a treasure hunt. ${ }^{2}$ In the search for African leadership treasure, I propose three clues: (1) pre-colonial Africa; (2) the period during colonisation; and (3) post-colonial Africa and the future.

1. The pre-colonial Africa treasure is hidden in traditional leadership practices that resulted in the construction of great structures. Nkomo (2006:1-2) notes that there are many examples of extraordinary African leaders who built great nations and structures such as Egypt and Great Zimbabwe. The other examples are King Sundiata and Emperor Mansa Musa of the great Mali Kingdoms and King Moshoeshoe of the Basotho. Despite the existence of emperors and kings, traditional forms of democracy held their ground. Rulers could seldom or never rule alone and they had to listen to their counsellors. O'Malley (2003:31) summarises pre-colonial leadership by stating that African society had until it was disrupted by the combined scourge of slavery, colonialism, racism and exploitation, a highly effective leadership system which was backed by traditional customs, philosophies, rituals and taboos. Africa's leadership problems started when western explorers, travellers or settlers sought to interpret its societal institutions and leadership systems according to their own mindsets and value-judgements. Nkomo (2006:12) adds that the proponents of African leadership seek to recommend this perspective on global partners, namely that Africans had management and leadership philosophy. The argument to extricate leadership lessons from precolonial Africa is noble but to some extent unhelpful unless moderated. Importing approaches of past centuries assumes that time and culture are static and, worse, that they can be reversed (Magezi 2006:2-4; Nkomo 2006:1). This overlooks the effect of the disruption and the space that African people presently find themselves in.

2. The period of colonisation resulted in disruption. Also notable is that African leadership systems were interpreted according to the mindsets and value-judgements already etched in the minds of foreign explorers, travellers or settlers (O'Malley 2003:85-87).

3. Post-colonial Africa is the Africa that Africans currently find themselves in. This period is characterised by leadership consciousness, optimism and a sense of deficiency. Despite limited scholarly articles citing African leadership, as Nkomo (2006) has noted, Swart (2008:9)

2.The description of a treasure hunt is as follows: It entails one or more players trying to find hidden articles, locations or places by using a series of clues. Treasure hunt games may be an indoor or outdoor activity. Outdoors it can be played in a garden or games may be an indoor or outdoor activity. Outdoors it can be played in a garden or org/wiki/Treasure_hunt_(game) observes that there is significant progress on leadership development efforts. Some of the key developments include the following: establishment of the African Leadership Council (2003) chaired by Sir Ketumile Masire of Botswana that comprises several former heads of state and cabinet ministers; the establishment of the African Leadership Initiative (2006); the Life After Leadership, which is the Mo Ibrahim Prize for Achievement in African Leadership; the Elders initiative called Leading by Example - The Elders; and Born, Bred or Taught? The Creation of the African Leadership Academy (2008).

A leadership renaissance is undoubtedly taking place at present. There is increased leadership consciousness that Africa needs to develop leaders that are competent to address African challenges. Research from the African Leadership Initiative (2006) recommends a leadership approach that is known as constellational leadership, rooted in the African tradition, to meet Africa's developmental needs and challenges and set an example to the world (African Leadership Group 2008). Swart (2008:11), citing Kumuyi (2007), aptly states that Africa is in dire need of a new form and type of leadership.

The present African leadership thinkers in South Africa are calling for the practice of African leadership encompassing a core approach of ubuntu or African humanism (Nkomo 2006:1-2). Mostert (2005:2) advances a similar argument of an African leadership approach that values people rather than individualistic Western models.

\section{African leadership for the future}

The African leadership hidden treasure seems to be trapped in Africa's former leadership approaches and the reality of Africa's present leadership. While scholars point to Africa's glorious past as evidence that a unique and effective form of leadership existed in Africa, these approaches have never been scientifically tested; hence, they lack efficacy (Nkomo 2006:2; O'Malley 2003:90). The expressed ideas of African leadership seem to focus on what should be and not necessarily what happens in practice. In fact, as Nkomo (2006:2) notes, one of the difficulties of developing a concept of African leadership is the contradictions and paradoxes posed by trying to define the very essence of African leadership. She explains that by calling for an 'African' leadership style, these African leadership thinkers imply Africa is homogeneous rather than multicultural and that a single African culture can form the basis of African leadership. A further challenge is the progress that has thus far been made in leadership development, particularly in South Africa. Venter (2012:1) reports that South Africa's business leadership potential is ahead of that in other countries in the BRIC grouping (Brazil, Russia, India and China) although it lags behind the developed G8 nations. In fact, black African leaders have learnt to suppress the African traditional tendencies that seem unfit for the boardrooms in order to function in the global leadership space. The argument that Africa's contribution to leadership is enshrined in $u b u n t u$, which is a concept that is often applied out of context, is simplistic. O'Malley (2003:90) 
remarks that the simplistic promotion of African leadership themes and values runs the risk of launching contemporary African society and its institutions on a retrogressive path. Such a path will lead to pre-historic African tribal life that exists only in the minds of romantic historians and writers of African fantasies.

I contend that the present realities of Africa require African leadership that is informed by at least four considerations. Firstly, the reality of cultural dynamics deriving from historical African roots is an important consideration. In this case, retrievable pre-colonial historical practices that strengthen African leadership going forward should be adopted. Secondly, realising the reality of present African leaders who are influenced by both African and Western values, which Mzondi (2009) in his doctoral thesis called 'two souls' of leadership. Thirdly, leaders should be cognisant of the global space that African and South African institutions exist in. This calls for a general degree of shared global leadership framework to be applied. Fourthly, there should be a concise articulation of the meaning of African leadership in order for a constructive dialogue on the global 'leadership menu table' to be present.

In view of the above submission, what are some of the precolonial practices that should be imported to present Africa to constitute the 'two souls' that inform contemporary African leadership approaches and consequently contribute to global leadership discussion? Nkomo (2006:1-2) avoids proposing some tenets of African leadership and rather opts for recommending research on the subject. The African Leadership Group (2008) recommends constellational leadership. Mostert (2005:2) proposes a form of African leadership that contributes to an insightful approach to leadership. He reasons that leadership is about leading people to have insight about themselves. The leader should genuinely strive to have people at heart. This in turn will inform quality decisions rather than individualistic benefits. In his detailed study spanning over two decades on African leadership analysis, O'Malley (2003:86-93) proposes ten detailed elements of African leadership. ${ }^{3}$

1. African leadership should bridge the conflict gap between African and foreign influences. Considering the long history of disruption and consequent Western influence, African leaders have to a large extent lost touch with most aspects of the institutions of traditional African leadership. This means that even though there is a need to claim the historical African leadership roots, the context in which African leaders operate requires them to be global human beings in order to effectively manage global corporations.

2. Despite the fact that some of the historical leadership practices are undocumented and scientifically untested, they should be incorporated if they contribute to progress in leadership thinking. African leaders should not shy away from promoting useful practices that add value to

3.These elements are discussed in detail in the article but here they shall be summarised. leadership thought. Concepts such as ubuntu should be critically incorporated in corporate leadership thinking.

3. There should be recognition of the lost relevance and diminishing support for some of the African traditional practices. The reality of consumerism and constitutional clashes between traditional practices and country constitutions continue to diminish the appreciation of traditional practices.

4. The enduring values of the African community, which is often a referred fact in Africa, should make a contribution to leadership. The ideas and values such as humanism, communalism, and altruism that seem to be in conflict with the truth should be reviewed. Lessons from African leadership institutions that practised such values as humanism or altruism should be learnt and applied.

5. African leadership ideas should be put forward by Africans and be tested.

6. The claim of African leaders as being strong in collective leadership as opposed to individual leadership needs to be tested.

7. The reality of leadership dualities where there should be a balance between strong egos with alter egos is a critical African leadership contribution.

8. There is a need for re-assessment and reclassification of practices. There is a need to re-evaluate the relevance or desirability of practices whose original motivations are neither compatible with the demands of a democratic open society nor justifiable on the grounds of including contemporary African morality and ethical codes and long-term national or continental African priorities. Undesirable practices should be dropped.

9. Despite many black African leaders' failures and premature termination of their own leadershipmanagerial careers, many others are benefiting from the crass mistakes of their colleagues. There is abundance of capacity among emerging black African leaders and managers.

10. There is a need to document the factors that make some African leaders good and bad in order to establish a robust African leadership system.

Some comments made by O'Malley (2003:86-93) are not tenets of African leadership per se but are rather principles to be observed in developing an African leadership approach. However, his ten points summarise the various offerings by other African scholars. From the foregoing discussion, I suggest that the African leadership tenets that could be noted to contribute to the leadership discussion are:

- Reality of the current space of African leaders entail the employment of an integrative approach of Western and African values, that is, two souls (Mzondi 2009).

- The values of humanism, communalism, and altruism enshrined in the notion of ubuntu should be integrated in leadership approaches.

- There has to be cognisance of the idea of kingship and gerontocracy as embedded values among African leaders. 
- The notion of not ruling alone while in leadership, which leads to establishment of balance of power, should be noted. The king and ruler lead with counsellors.

- The leader or king identifies with his people. His identity is intricately linked with his people. The king and his people are one.

Thus, while the treasure of African leadership may remain hidden and unfound, the above clues may be a beginning compass towards articulating African leadership. The question, however, is: how could these African leadership elements be integrated with the biblical notion of servant leadership to inform African church leaders? To respond to this question, one has to understand the meaning of biblical servant leadership, to which we now turn.

\section{Kingship and servanthood merged: From general servant leadership to biblical servant leadership}

The term servant leadership was coined by Robert Greenleaf (1904-1990) in 1970. Van Dierendonck (2011:1228-1229) and Graham (1991) note that in our times of individualism, servant leadership is particularly relevant because it adds the component of social responsibility to transformational leadership. Van Dierendonck (2011:1228-1229) describes servant leadership as follows: it is demonstrated by empowering and developing people; by expressing humility, authenticity, interpersonal acceptance, and stewardship; and by providing direction. Considering the fuzziness of this definition, it is worthwhile to consider the description of servant leadership. A servant leader is an individual who begins with the natural feeling that one wants to serve. Then this conscious choice brings one to aspire to lead. The best test for servant leadership is summed up in the answers to the following questions: Do those served grow as persons? Do they, while being served, become healthier, wiser, freer, more autonomous, and more likely themselves to become servants? And, what is the effect on the least privileged in society? Will they benefit, or at least not further be harmed? Thus servant leadership places 'going beyond one's self-interest' as a core characteristic. In comparison to other leadership theories, servant leadership emphasises the importance of follower outcomes in terms of personal growth without necessarily being related to organisational outcomes.

Literature on servant leadership highlights that for a servant leader power is the possibility to serve others and may even be considered a prerequisite for servant leaders. Serving and leading become almost exchangeable in servant leadership. Being a servant allows a person to lead; being a leader implies that a person serves (Phipps 2010:7; Van Dierendonck 2011:1230; Vondey 2010:3). Servant leaders are motivated by something more important than the need for power, namely, the need to serve (Luthans \& Avolio 2003). Indeed Van Dierendonck (2011:1254) rightly concludes his article by saying, 'servant leadership is an intriguing new field of study for management researchers'. However, how is servant leadership in leadership and management literature different compared to biblical servant leadership?

Servant leadership as contained in management literature is different from a biblical view of servant leadership. Even though some elements of servant leadership and biblical leadership may overlap, there are clear differences, at least in the following five areas: reference, guiding principles, motivation, agent and goal. The reference point is Jesus as king and servant, the guiding principles are drawn from the normative source - the scriptures; motivation is the realisation of God's kingdom on earth; agent refers to the embodiment of the biblically desired leadership by human leaders; and the goal is faith development. This framework of servant leadership suggests that the locus and context of biblical leadership is the church, although the reach is both to the faith community and to the larger public.

Biblical servant leadership should be understood from God's perspective of leadership as outlined in the normative source - the scriptures. Kingship as the institution that was responsible for leading God's people, had clear prescriptions. However, prior to the establishment of kingship, Israel's leadership inaugurated by Moses was charismatic leadership. Tushima (2012:164-166) explains that charismatic refers to the combined factors of a person being elected by the deity for some special task and therefore uniquely endowed with the enabling presence of the deity, as manifested by the descent of the deity's spirit upon the person or some other palpable evidence of divine presence upon the person coupled with the individual's manifestation of exceptional abilities, especially with respect to securing deliverance for his or her people. Joshua, Moses' successor, continued in the same tradition of charismatic leadership until the time of the judges ended with the institution of kingship.

The prescription for kingship is outlined in Deuteronomy 17:14-20. The way the Israelite kings were to be distinct and unlike the other nations as outlined in Deuteronomy 17:14-20 consisted of three prohibitions, namely, non-proliferation of horses, wives, and wealth, and three prescriptions, namely, copy the law, study the law, and obey the law. Tushima (2012:169) observes that the three prohibitions relate directly to the lifestyles of ancient Near Eastern kings: the pursuit of a strong military for security and territorial expansionism (represented by the horses), political alliances (represented by wives), and accumulation of wealth often associated with the oppression and exploitation of the weak both within the monarch's realm (through excessive taxation and other oppressive practices) and outside of it (through wars, conquests, or levy of tributes). These are the very things from which Israel's charismatic leadership (even in a monarchical form) was to refrain. Reliance on military strength would take Israel's focus away from God, their true King and the One who also led them in their wars (Dt 20:1; cf. Dt 31:1-6; Jdg 7:2; 2 Chr 32:1-8). Political alliances with their concomitant marriages would obliterate Israel's distinctiveness through religious perversion (Dt 17:17; cf. Dt 7:3-4; Jos 23:12-13; Jdg 
3:6-7; 1 Ki 11:1-4). Similarly, multiplication of wealth always went together with the perversion of justice, oppression and exploitation of the poor and powerless, which Israel was prohibited from indulging in (Dt 16:19; 24:14-15; 27:19).

To ensure the kings' obedience they had to keep a copy of the law, study the law, and obey the law. Israel's kingship was aimed at helping God's people to remain in submission and obedience to their true sovereign God. Tushima (2012:169) claims that this Deuteronomic leadership ideal was exemplified by Moses (cf. Ex 32:30-32; Nm 12:3; Dt 3:23-28; 4:21-22), upheld and embodied by Samuel (1 Sm 12:1-4), and fulfilled in Josiah. This model of leadership finds its consummate fulfilment in Jesus of Nazareth, and it is the ideal that he modelled and taught to his disciples (Mk 10:4245; Lk 22:24-26).

The instructions from the leadership ideals of kings and its fulfilment in Jesus Christ clearly indicate the ideals of biblical servanthood. Boa (2006:1) and Beswick (2013:1) comment that even though Jesus was king and great, he was a servant. Jesus the king identified with his people and felt for them. Learning from John 13, Jesus did the unthinkable in fulfilling the servant role. He washed his disciples' feet. In doing so, Jesus acted and taught against the culture of the day, thereby demonstrating that the kingdom of God values servanthood. Thus he rebuked and instructed in his actions. In a graphic way, referring to the incident of John 13:1-20, Boa (2006) wisely comments:

[T] he wisdom of God that restrains the untamed fury of the waters that are above the firmament that sets a bridle on the deep and keeps back the seas now pours water into a basin and the Master washes the feet of His servants. The Master shows to His disciples an example of humility. He who wraps the heavens in clouds girds Himself with a towel. And He in whose hand is the life of all things kneels down to wash the feet of His servants. (p. 1)

Referring to Jesus' humble actions in washing the disciples' feet, Beswick (2013:1) concludes that taking the role of servant was not denying his leadership; he continued to bear the responsibilities that had been given to him by the Father. What he did was to provide a model for a new kind of leadership, namely the servant leader. As he said to the disciples: 'Whoever wants to be first must be last of all and servant of all' (Mk 9:34-35). Jesus' teachings and actions were radical and revolutionary. He demonstrated a radically different kind of society and leadership. Beswick (2013:1) said it is not one in which there is no leadership, or no authority, let alone no responsibility. Jesus in his teachings and actions modelled and warned those who are obsessed with equality and those who may stage humility as people against true servant leadership. In an insightful way, Gumbleton (2013) goes against the tide by saying, in view of how kings are known, that Jesus may not be king in that sense. Kings have power; kings have wealth; kings lord things over others; kings use force and killing to get their way, but with Jesus none of these are true. Jesus the Servant King identifies with his people and serves them in the most unimaginable way (Is 53).
The foregoing discussion revealed that while there is reference to servant leadership in management literature, there is a variation to the meaning of servant leadership when viewed from the dimension of biblical servant leadership. Biblical servant leadership draws reference from Jesus Christ. Jesus was the king and a servant at the same time. The merging of kingship and servanthood in Jesus, the dimensions he taught and demonstrated, provides reference and example. Carroll (2011:7) rightly asserts that Christian leadership finds its identity and purpose in the story of Jesus and the story of the people of Israel - Jesus being the fulfilment of Israel. The principles and guidelines of such leadership are drawn from the scriptures. The church leaders who are instruments responsible for executing leadership should be charismatic, sensitive and conscious of God's desire of leading his people. They should be aware that they are leading people on behalf of God. Accordingly, the motivation and goal of biblical servant leaders should be in sync with God's purpose of ushering in and demonstrating his kingdom. Thus, in this case, servant leadership as taught in management and profit making corporations differs, although there may be similarities in practice.

In view of the above, how then may the African church leader discern and practise biblical servant leadership in a space where there is influence of African culture and normative biblical leadership values?

\section{Towards a Christian leadership model: A king who is a servant as leadership transformation in African church leadership}

Louw (2011:1-2) in his assessment of practical theology concludes that practical theology is that field within theology that deals with the praxis of God. It entails understanding the implications of the God-human encounter for life. He adds that practical theology is interested in the intention, motivation and telos [purposeful meaning] of human actions within the field of ministry, communities of faith and social contexts. In this regard, it tries to link appropriate understandings of God with the pastoral and hermeneutical endeavour of understanding the salvific actions of God and his presence in life events. Within Christian leadership development, a specific understanding of both the power of the church and its leaders and the power of God is needed. Louw (2011:3-4), citing Hall (1993:106), points out that the notion of an authoritative powerful church-praxis that is contrary to tenderness and weakness should be abandoned. I therefore propose that the church and its leaders should explore and embrace an understanding of God and his Son Jesus where he is both king and servant, for leadership that is both constructive and service oriented. Jesus was the king and a servant at the same time. As described above, Jesus taught and demonstrated servant leadership as a king. 


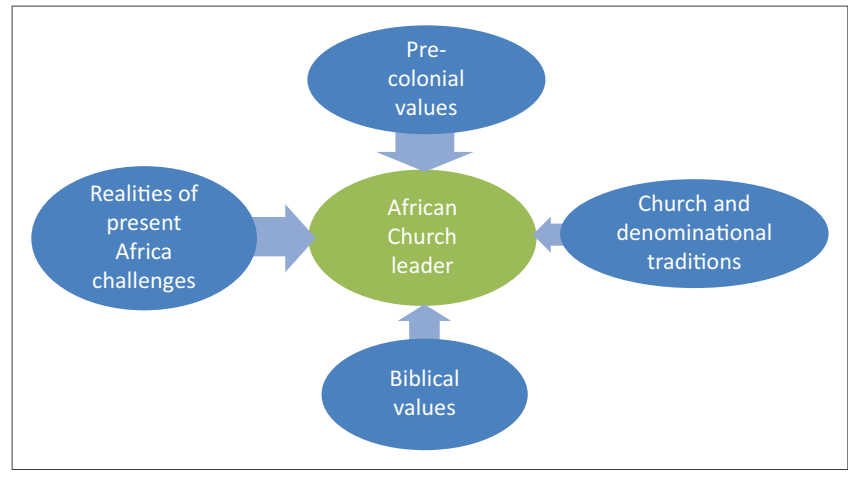

FIGURE 1: Interaction of African culture, modernity, church and denominational traditions, and biblical frameworks on leaders.

The African leader is sandwiched between African culture, modernity, church and denominational traditions and biblical frameworks of leadership as indicated in Figure 1.

Mzondi (2009:iv) referred to African leaders as having 'two souls', meaning that they are influenced by both Western and African values to the extent that they operate unconsciously of the influences. On the one hand there is backward looking of African church leaders to the old practices of pre-colonial times and, on the other hand, the current context. The historical kingship practices and its challenges as well as contemporary challenges, such as consumerism, should be transformed by biblical servant leadership principles. Church leaders who amass wealth, establish themselves as super human beings, do not account to church members, swindle the flock or use all sorts of cunning methods, are encouraged to embrace the Deuteronomic leadership ideal of servant kings that was demonstrated by Jesus. The leader should identify with the struggles and needs of his people (Is 53). It is inconceivable for a church leader to be apathetic and ignore the needs and concerns of the people under his care. The leader should be 'one' with his people.

Church leaders are reminded, to the extent possible, of the African values of humanism, communalism, and altruism, enshrined in the notion of $u b u n t u$, which should be integrated in leadership approaches. However, the motivation should be the service of one another as demonstration of God's kingdom on earth. The focus should be to contribute to the development of people's faith and the glorification of God. Even in situations where church leaders are called to perform a public role, the fundamental principle of representing God's kingdom should be emphasised. Applying the Deuteronomic leadership ideal of kings, church leaders should be different from the other people, that is, those who are not of the faith.

The idea of kingship and gerontocracy being key values among African people should be moderated. The model of Jesus as king, but at the same time a servant, should be adopted to influence selfless leadership. Instead of leaders to be treated first and in opulence, they should put the people and their interests first under their leadership. While leaders occupy a special respected place in the life of Africans within the church community, an assessment should be made to determine their level of spiritual maturity. Furthermore, there has to be continuous assessment of the extent to which a community plays a constructive or destructive role and moderate accordingly (Magezi 2006:3-5).

By establishing church leadership comprising a number of elders, there is balance of power among church leaders. Indeed the king or ruler needs a council to advise him. This, therefore, resonates with the eldership council among African communities. The concern should be the quality of the people comprising the council. Both council members and the leader should be conscious of the need for spiritual guidance in leadership.

The foregoing propositions assume that the church leader is an eschatological being operating within the now 'as already saved' and the 'not yet' kingdom to come. It implies that the being of the person in leadership is a pneumatological being. Therefore, to view church leadership as the praxis of God means the leader 'enfleshes' and embodies the engagement of God with life. In this regard, church servant leadership should be a hermeneutical endeavour of understanding the salvific actions of God and his presence in life events. A Christian leader's 'being' should be pneumatological, in order to function within the framework of biblical servanthood principles. It is when a leader is operating as a pneumatological being that sense, meaning and understanding of the true sense of the Godimage of God as king who is a servant and vulnerable could make sense. This according to Paul, is what he calls foolishness from the eyes of the world (1 Cor 3:19). Thus, Carroll's (2011:7) observation that Christian leadership finds its identity and purpose in the story of Jesus and the story of the people of Israel is a critical guide to church leadership.

\section{Conclusion}

The above discussion revealed that Christianity is mediated through culture and people's cultural practices. It discussed African leadership and its associated characteristics. Secondly, it discussed servant leadership with particular focus on biblical servant leadership. Thirdly, it proposed an integrated transformational leadership model employing a paradoxical God-image of Servant King as king with power but vulnerable and serving that is informed from the biblical kingship ideal that was fulfilled in Christ. The discussion revealed that it may be a futile exercise for African leaders to be backward looking to pre-colonial times, as opposed to rather focusing on retrieving some African leadership elements that are still relevant to contemporary Africa. These elements could also contribute to global leadership discussion. However, these elements need to be moderated and integrated with biblical leadership principles to develop a constructive and responsible African Christian leadership. Such a leadership style is possible when the leader is operating within a pneumatological framework. 


\section{Acknowledgements Competing interests}

The author declares that he has no financial or personal relationships which may have inappropriately influenced him in writing this article.

\section{References}

African Leadership Group, 2008, 'The mission to explore African Leadership', viewed 20 January 2015, from http://www.africanleadership.co.za/about-alg/our-journey/

Alexander, R., 2012, 'Why do so many African leaders die in office?', in BBC News, viewed 14 May 2015, from http://www.bbc.com/news/magazine-19356410

Barker, R.A., 2002, On the nature of leadership, University Press of America, Lanham, MD.

Beswick, D., 2013, 'The servant king', viewed 20 December 2014, from http://www. beswick.info/rclresources/L6C95Ser.htm

Boa, K., 2006, 'Servant leadership', viewed 19 January 2015, from https://bible.org/ seriespage/43-servant-leadership-part-1

Carroll, J.W., 2011, As one with authority, 2nd edn., Cascade Books, Eugene, OR.

Ceglowski, J., 1998, 'Has globalization created a borderless world?', viewed 13 May 2015, from www.phil.frb.org/research-and-data/publications

Graham, J.W., 1991, 'Servant leadership in organizations: Inspirational and moral', Leadership Quarterly 2, 105-119. http://dx.doi.org/10.1016/1048-9843(91)90025-W

Guenther, B.L. \& Heidebrecht, D., 1999, 'The elusive biblical model of leadership', Direction 28(2), 153-165, viewed 10 January 2015, from http://www. directionjournal.org/28/2/elusive-biblical-model-of-leadership.html

Gumbleton, T., 2013, 'Jesus is a king, but not a king in the world's definition', Nationa Catholic Reporter, viewed 05 January 2015, from http://ncronline.org/blogs/ peace-pulpit/jesus-king-not-king-worlds-definition

Igué, J.O., 2009, 'A new generation of leaders in Africa: What issues do they face?' International Development Policy, Revue internationale de politique de développement, viewed 13 May 2015, from http://poldev.revues.org/139, http:// dx.doi.org/10.4000/poldev.139

Louw, D.J., 2011, 'Ta splanchna: A theopaschitic approach to a hermeneutics of God's praxis: From zombie categories to passion categories in theory formation for a practical theology of the intestines', HTS Theological Studies/Teologiese Studies $67(3), 65-77$. http://dx.doi.org/10.4102/hts.v67i3.1087

Luthans, F. \& Avolio, B., 2003, 'Authentic leadership development', in K.S. Cameron \& J.E. Dutton (eds.), Positive organizational scholarship, pp. 241-254, BerrettKoehler, San Francisco, CA.

Magezi, V., 2006, 'Community healing and the role of pastoral care to the ill and suffering in Africa', In die Skriflig 40(3), 1-17. http://dx.doi.org/10.4102/ids.v40i3.356
Mostert, M., 2005, 'African leadership: People solutions for African challenges', Management Today, April, 26-27.

Mzondi, A.M.M., 2009, “Two souls" leadership: Dynamic interplay of Ubuntu, Western and New Testament Leadership values', DLitt et Phil thesis, University of Johannesburg.

Nkomo, S., 2006, 'In search of African leadership', Management Today, June, 1-2.

Oladosu, J., 2005, 'Designing viable republican constitutions for modern African states: Why the institution of traditional kingship must be abolished', PhD thesis, Dept. of Philosophy Obafemi Awolowo University, Ile-Ife, Nigeria.

O'Malley, P., 2003, 'The African leadership experience: A foundational report of findings and observations from an exploratory assessment of the history and evolution of the concept of leadership with reference to the development of an African leadership approach', viewed 17 January 2015, from https://www. nelsonmandela.org/omalley/index.php/ site/q/03/v03445/04lv04015/05lv04154 /06lv04196/07lv04199.htm

Onike, R., 2012, 'Kingship and gerontocracy as core African traditions', viewed 17 January 2015, from http://searchwarp.com/swa857950-Kingship-AndGerontocracy-As-Core-African-Traditions.htm

Pfarelo, E.M.P.E., 2013, 'The role of Makhadzi in traditional leadership among the Venda', PhD thesis, Faculty of Anthropology and Development Studies, University of Zululand.

Phipps, K.A., 2010, 'Servant leadership and constructive development theory: How servant leaders make meaning of service', Journal of Leadership Education 9(2), 151-170.

Rost, J.C. (ed.), 1993, Leadership for the twenty-first century, Praeger, Westport, CT.

Smit, A., 2012, 'Leadership challenge for Africa: The challenge for Africa is to not only develop the next generation of leaders but to develop responsible leaders', HR Future, viewed 16 January 2015, from http://www.hrfuture.net

Swart, G., 2008, 'Africa leads the way: The trends and triumphs of the continent's leadership renaissance', African Renaissance 5(1), 9-17.

Tushima, C.T.A., 2012, 'A king under the law: The Torah promulgation and its subversion in Jeremiah', Old Testament Essay 25(1), 162-181.

Van Dierendonck, D., 2011, 'Servant leadership: A review and synthesis', Journal of Management 37(4), 1228-1261. http://dx.doi.org/10.1177/0149206310380462

Van Dyk, G.A.J. \& Van Niekerk, N.J., 2004, 'Military leadership: A challenge beyond full range leadership', Journal of Public Administration 39(2), 322-340.

Venter, N., 2012, 'Announcing the SHL Leadership Index@ for South Africa businesses: South Africa's leadership potential is ahead of the BRICS but behind the G8' Management Today, May, 11

Vondey, M., 2010, 'The relationships among servant leadership, organizational citizenship behavior, person-organization fit, and organizational identification International Journal of Leadership Studies 6(1), 3-27.

Wikipedia, the free encyclopedia, 2007, 'Treasure hunt (game)', viewed 20 January 2015, from http://en.wikipedia.org/wiki/Treasure_hunt_(game)

Winston, B.E. \& Patterson, K., 2006, 'An integrative definition of leadership', International Journal of Leadership Studies 1(2), 6-66. 